\title{
Mendicodinium morgenrothum, a new species of dinocyst from the Middle Jurassic, Aalenian to lowermost Bajocian Ness Formation (Brent Group), northern North Sea
}

\author{
NICK BUTLER \\ Simon Petroleum Technology Exploration Services Ltd, Llandudno, Gwynedd LL30 1SA, UK.
}

\begin{abstract}
A new dinocyst species Mendicodinium morgenrothum is described from the Middle Jurassic, Aalenian to lowermost Bajocian Ness Formation (Brent Group) of the North Viking Graben area of the North Sea. J. Micropalaeontol. 14(1): 25-28, April 1995.
\end{abstract}

\section{INTRODUCTION}

The Middle Jurassic, Aalenian to lowermost Bajocian Ness Formation (Brent Group; Deegan \& Scull, 1977; Vollset \& Dore, 1984) is a sequence of coastal plain, deltaic sediments consisting of interbedded sandstones, mudstones and coals (Scotchman \& Johnes, 1990). A palynological investigation of core pieces from this formation in the Amoco (UK) operated Northwest Hutton Field (Block 211/27; Fig. 1) was undertaken as a major part the author's doctoral studies at the University of Sheffield, UK. A low diversity microplankton assemblage from brackish water, lagoonal facies in the lower part of the formation has yielded a previously undescribed species of the dinocyst genus Mendicodinium Morgenroth, 1970.

All illustrated specimens are housed at the Centre for Palynological Studies, University of Sheffield, UK.

\section{SYSTEMATIC DESCRIPTION}

Division Pyrrhophyta Pascher, 1914

Class Dinophyceae Fritsch, 1929

Order Indeterminate

Family Indeterminate

Genus Mendicodinium Morgenroth, 1970

Mendicodinium morgenrothum sp. nov.

$$
\text { Pl.1, figs 1-9 }
$$

Derivation of name. In recognition of the early pioneering palynological research of Peter Morgenroth into Jurassic dinocysts.

Diagnosis. Cysts proximate, outline subcircular. Autophragm scahrate or micropunctate ornamented with scattered to densely distributed errucae. Tabulation not indicated although cingulum detined by reduced ornament. Archaeopyle epitractal, presumed tAtP.

Holotype. Slide ML 2162, England Finder reference H66/3, Pl.1, fig.1.

Paratype Slide ML 2162, England Finder reference E34/2, Pl.1, fig.2.

Locality and horizon. Amoco UK well 211/27-A22, Northwest Hutton Field, North Sea. Interpreted Aalenian-lowermost Bajocian at $12685.5^{\prime} \log$ measured depth (12674.5' driller's depth) from the released cut (core pieces) at the British Geological Survey, Edinburgh, UK; lower Ness Formation, Brent Group.

Description. Outline is subcircular in dorso-ventral compression. The hypotract is slightly larger than the epitract. The cysts are proximate with autophragm only which is approximately $1 \mu \mathrm{m}$ in thickness and sometimes folded. The autophragm is scabrate, micropunctate or microfossulate and ornamented with scattered to densely distributed verrucae which may occur as clusters touching adjacent verrucae but never coalescing or fusing. This ornament occurs on both ventral and dorsal surfaces. It is consistently reduced in the cingular region only, where the autophragm is smooth or scabrate. An omphalus is usually present, attatched to the inner surface of the cyst, generally in the sulcal region. There is no evidence of tabulation, apart from the laevo-rotatory cingulum precluding classification of the species at order and family level. The archaeopyle is epitractal, presumed type tAtP. The hypotract and epitract remain attatched at the sulcal - presumed 1' plate boundary.

Dimensions. Body diameter at the paracingulum 51$89 \mu \mathrm{m}$, mean $62.5 \mu \mathrm{m}$, holotype $66 \mu \mathrm{m}$; verrucae $1-2 \mu \mathrm{m}$ in diameter (although occasionally upto $5 \mu \mathrm{m}$ ) and $1-2 \mu \mathrm{m}$ in elevation (17 measured specimens).

Comparison. Mendicodinium morgenrothum sp.nov. is distinguished from Mendicodinium granulatum Kumar, 1986 which is granulate, from Mendicodinium microreticulatum Kumar, 1986 which is microreticulate and from Mendicodinium caperatum Brideaux, 1977 which is granulate and microreticulate. It is differentiated from Mendicodinium groenlandicum (Pocock \& Sarjeant, 1972) Davey, 1979 which is unornamented and from the type species Mendicodinium reticulatum Morgenroth, 1970 which is reticulate.

Remarks. This species has been consistently encountered in Ness Formation strata across the North Viking Graben and generally occurs in association with other dinocysts such as Nannoceratopsis gracilis Alberti, 1961 emend van Helden, 1977, Nannoceratopsis senex van Helden, 1977 and Mancodinium semitabulatum Morgenroth, 1970. The presence of Nannoceratopsis triceras Drugg, 1978 in the overlying Ness Formation interval from the type well indicates an age no younger than the lowermost Bajocian H.discites Ammonite Zone (Woollam \& Riding, 1983; Riding et al., 1991; Mitchener et al., 1992). Regional evidence and the first downhole appearance (FDA) of the Family Phallocystaceae Dorhofer \& Davies, 1980 (or the Parvocysta group of dinocysts of Woollam \& Riding, 1983) in the underlying fully marine upper Drake Formation (Dunlin Group) suggests an age no older than the latest Toarcian or earliest Aalenian for the overlying 


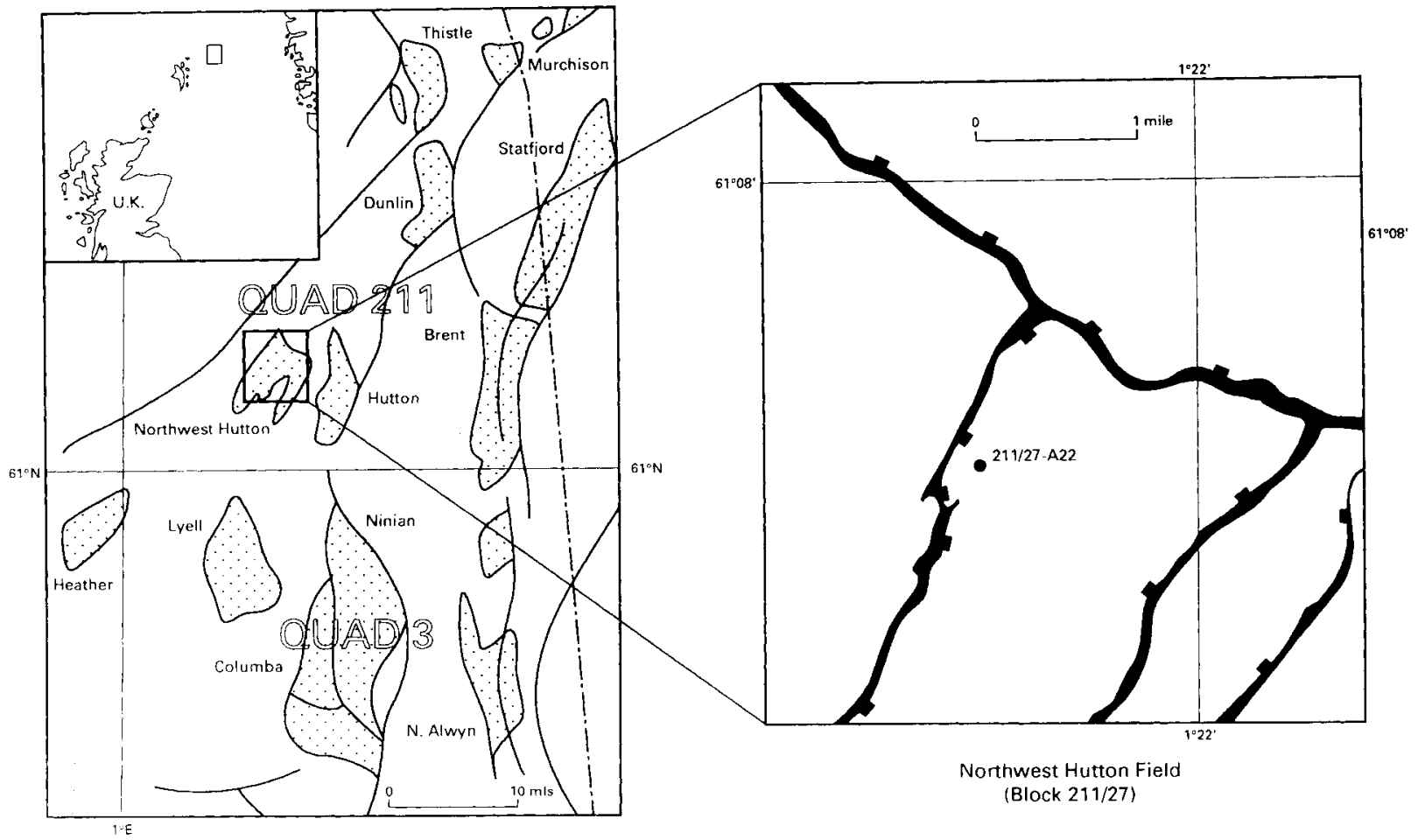

Fig. 1. Location map of the Northwest Hutton Field, top Brent Group structure map and location of well 211/27-A22 (after Scotchman \& Johnes, 1990).

deltaic Brent Group (Woollam \& Riding, 1983; Prauss, 1989; Riding et al., 1991). However, this latter datum may be debatable as there is a major change in facies associated with the deposition of the more brackish Brent Group.

\section{ACKNOWLEDGEMENTS}

The author wishes to thank the directors of SPT Exploration Services Ltd for the use of its technical facilities and permission to publish this paper. I am grateful to Roger Davey for critically reading the manuscript. I am also grateful to Amoco (UK) for the tenure of an Amoco Studentship and permission to publish. Thanks are also due to members of staff and postgraduate students at the Centre for Palynological Studies, University of Sheffield, particularly Roger Neves, Ted Spinner and John Keating.

\section{Manuscript received January 1993 Manuscript accepted April 1994}

\section{REFERENCES}

Alberti, G. 1961. Zur Kenntnis mesozoischer und alttertiarer Dinoflagellaten und Hystrichosphaerideen von Nort- und Mitteldeutschland sowie einigen anderen europaischen Gebieten. Palaeontographica Abt A, 116: 1-58.

Brideaux, W.W. 1977. Taxonomy of Upper Jurassic-Lower Cretaccous microplankton from the Richardson Mountains, District of Mackenzie, Canada. Geological Survey of Canada, Bulletin, 281: 1-53.

Davey, R.J. 1979. The stratigraphic distribution of dinocysts in the Portlandian (latest Jurassic) to Barremian (Early Cretaceous) of northwest Europe. American Association of Stratigraphic Palynologists, Contributions Series 5B: 48-81.

Deegan, C.E. \& Scull, B.J. 1977. A standard lithostratigraphic nomenclature of the Central and Northern North Sea. Report of the Institute of Geological Sciences, 77/25: 1-36.

Dorhofer, G. \& Davies, E.H. 1980. Evolution of archaeopyle and tabulation in Rhaetogonyaulacinean dinoflagellate cysts. Royal Ontario Museum, Life Sciences Miscellaneous Publications: 1-91.

Drugg, W.S. 1978. Some Jurassic dinoflagellate cysts from England, France and Germany. Palaeontographica Abt B, 168: 61-79.

Fritsch, F.E. 1929. Evolutionary sequence and affinities among the Protophyta. Biological Review, 4: 103-151.

\section{Explanation of Plate 1}

All magnifications are $\times 450$ except fig. 3 , all depths are log measured depth. Mendicodinium morgenrothum sp. nov. Figs 1, 3. Holotype. UK well 211/27-A22 (Northwest Hutton Field), $12685.5^{\prime}$ (core piece), slide ML 2162, EF H66/3 (Fig. 3 illustrates detail of the hypocystal ornamentation at $\times 2500$ magnification). Fig. 2. Paratype. UK well $211 / 27-A 22,12685.5^{\prime}$ (core piece), slide ML 2162, EF E34/2. Fig. 4. UK well 3/4a-12 (Strathspey Field), 10086.0' (core piece), slide ML 2165, EF N60/2. Fig. 5. UK well 3/8a-9A (Columba Field), 11 943.5' (core picce), slide ML 2167, EF H31/0. Fig. 6. UK well 3/3-C13 (Ninian Field), 12627.5' (core piece), slide ML 2166, EF F67/2. Fig. 7. UK well 211/27-A22, 12685.5' (core piece), slide ML 2164, EF Q60/3. Fig. 8. UK well 211/27-A22, 12685.5' (core piece), slide ML 2163, EF H35/1. Fig. 9. UK well 211/27-A22, $12685.5^{\prime}$ (core piece), slide ML 2164, EF C60/1. 


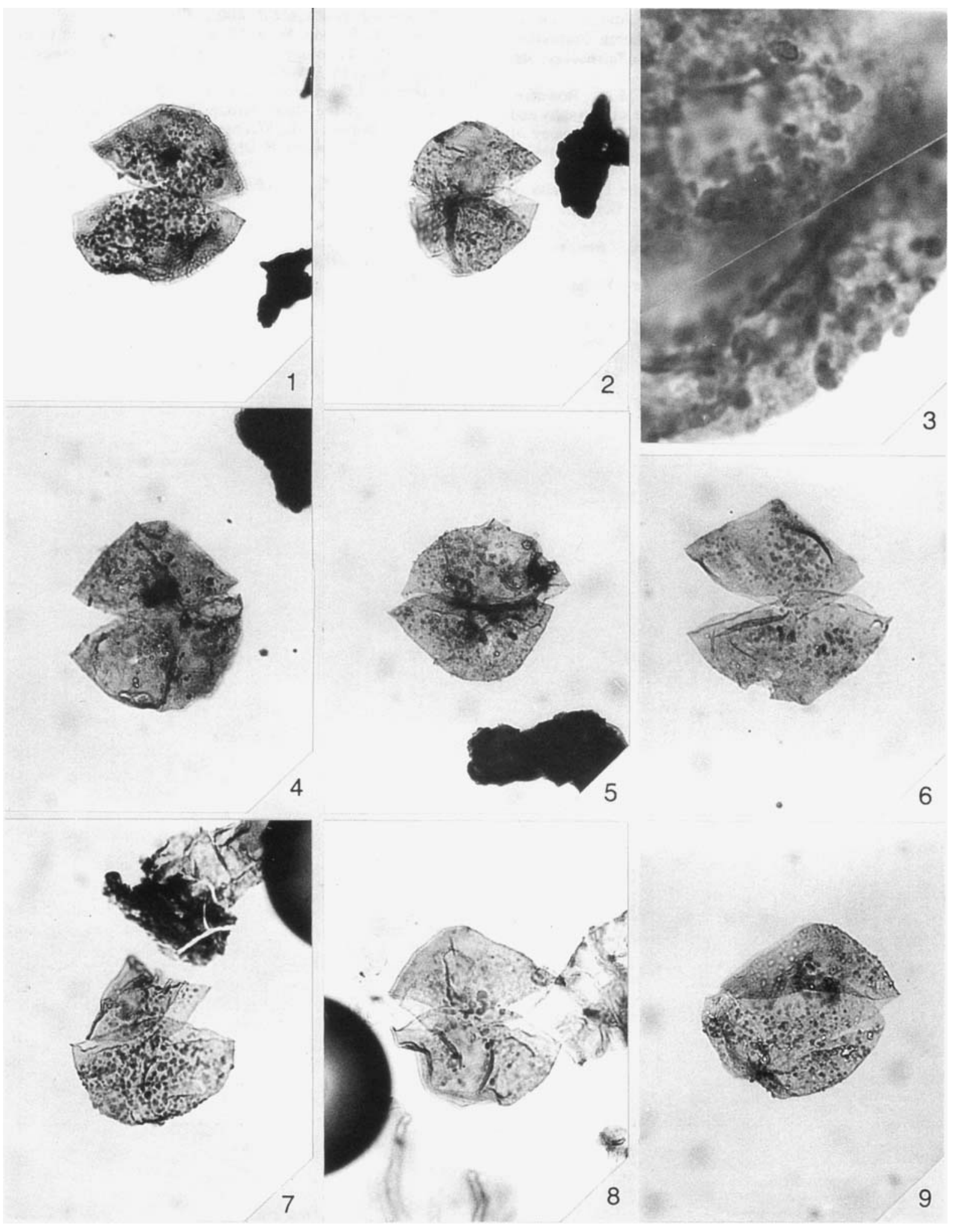


van Helden, B.G.T. 1977. Correlation of microplankton assemblages with ammonite faunas from the Jurassic Wilkie Point Formation, Prince Patrick Island, District of Franklin. Geological Survey of Canada, Paper, 77-1B: 163-171.

Kumar, A. 1986. A dinocyst assemblage from the Middle Member (Lower Kimmeridgian to Tithonian) of the Jhuran Formation, Kachchh, India. Review of Palaeobotany and Palynology, 48: $377-407$.

Mitchener, B.C., Lawrence, D.A., Partington, M.A., Bowman, M.B.J. \& Gluyas, J. 1992. Brent Group sequence stratigraphy and regional implications. In: Morton, A.C. et al. (Eds), Geology of the Brent Group. Geological Society, London, Special Publication, 61: 45-80.

Morgenroth, P. 1970. Dinoflagellate cysts from the Lias Delta of Luhnde, Germany. Neues Jahrbuch fur Geologie und Palaeontologie, Abhandlungen, 136(3): 345-359.

Pascher, A. 1914. Uber flagellaten und algen. Berichte der Deutschen Botanischen Gesellschaft, 36: 136-160.

Pocock, S.A.J. \& Sarjeant, W.A.S. 1972. Partitomorphitae, a new subgroup of Triassic and Jurassic acritarchs. Geological Society of Denmark, Bulletin, 21: 346-457.

Prauss, M. 1989. Dinozysten-stratigraphic und palynofazies im oberen Lias und Dogger von NW Deutschland. Palaeontographica Abt B, 214: 1-124.

Riding, J.B., Walton, W. \& Shaw, D. 1991. Toarcian to Bathonian (Jurassic) Palynology of the Inner Hebrides, Northwest Scotland. Palynology, 15: 115-179.

Scotchman, I.C. \& Johnes, L.H. 1990. Wave-dominated deltaic reservoirs of the Brent Group, Northwest Hutton Field, North Sea. In: Barwis, J.H., McPherson, J.G. \& Studlick, J.R.J. (Eds), Sandstone Petroleum Reservoirs, 227-261, Springer-Verlag New York.

Vollset, J. \& Dore, A.G. (Eds) 1984. A revised Triassic and Jurassic lithostratigraphic nomenclature for the Norwegian North Sea. Norwegian Petroleum Directorate Bulletin, 3: 1-53.

Woollam, R. \& Riding, J.B. 1983. Dinoflagellate cyst zonation of the English Jurassic. Report of the Institute of Geological Sciences, 83/2: $1-42$. 